\title{
Journalistik om flere af verdens mange virkeligheder
}

\section{AF LARS KABEL}

Nye danske og britiske undersøgelser af mediedækningen af ikkevestlige lande og kulturer dokumenterer det velkendte negative billede, men et nybrud er på vej. Globaliseringen og journalistikken om de civile samfund jorden rundt fordrer justerede arbejdsmetoder. Denne artikel belyser 'global journalism' og forskellige faglige begreber og tankegange til brug for et journalistisk udviklingsarbejde med en mere kultursensitiv udlandsdækning i nyheder og reportage.

Scenen var Statsministeriet, datoen 7. februar 2006. Anders Fogh Rasmussen og Per Stig Møller holdt pressemøde om reaktionerne på Muhammed-tegningerne. Verdenspressen var 'on location' på Christiansborg, hvorfra blandt andre DR, TV2, BBC og CNN transmitterede direkte. 12-13 radio- og tv-stationer og en talrig skare af Christiansborg-journalister og udenlandske reportere bragte ministrenes officielle budskaber kloden rundt: „Demonstrationerne i gaderne i de muslimske lande kan ikke loengere inddoemmes. Protesterne er ude af regeringers kontrol“.

I februar 2006 var København et internationalt brændpunkt, og i timerne op til pressekonferencen var stemningen i Statsministeriet spændt. RAI fra Italien var der, CBC fra Canada og Al-Jazeera fra Qatar med en journalist og et kamerahold.

Under sagen om Muhammed-tegningerne blev medierne i sig selv betydningsfulde emner for politisk debat, analyser og mediedækning. Som et spejl af dette ville en dansk journaliststuderende tage et billede af Al-Jazeera-mikrofonen med det verdens- 
berømte logo og af den arabiske tv-journalist, men det måtte han ikke. På sekunder opstod der en anspændt situation. Den arabiske reporter skjulte mikrofonen med logoet under noget papir og udbrød, at han ville smadre danskerens digitalkamera. Truslen hørte en dansk pressefotograf, og den var tydeligvis en overskridelse af hans grænser. Han satte sit store kamera lige op i hovedet på den arabiske tv-journalist, og som en form for kulturel manifestation var han parat til fotografering. Inden episoden løb af sporet, blev den dog inddæmmet. Pludselig stod der to hærdebrede vagtmænd af typen sorte briller og ulasteligt jakkesæt meget tæt på Al-Jazeera-reporteren.

Episoden varede blot sekunder, men var tankevækkende. Et øjebliksbillede på den mangel på interkulturel forståelse og accept, som sagen om Muhammed-tegningerne blandt andet handlede om og hvor endda "Small forms of cultural deviance may lead to major moral panics" (Ginneken, 2003: 206).

Reaktionerne i Statsministeriet illustrerede, at der selv i kosmopolitiske mediekredse hersker en manglende viden om og fornemmelse for, hvad der er norm og acceptabelt i fremmede lande og kulturer. I Danmark såvel som i arabiske nationer og muslimske samfund.

Den gensidige forståelse er begrænset. Nok har vi adgang til endeløse mængder af fakta om demografi, økologisk balance eller ubalance, eksportstatistikker, indkomstforskelle, landbrugsog industriproduktion, bruttonationalprodukt, byudvikling og turistseværdigheder, men vi deler ikke i samme omfang en reel viden om livsstil, religion og de bærende kulturelle søjler, der er fundamentet for, hvordan livet udfoldes og samfundet organiseres i fjerne lande og kulturer. Vores og deres meget forskellige handlinger og reaktionsmønstre bliver uforståelige og skræmmende, verdenen bliver skarpt delt op i dem og os.

I denne sammenhæng har mediedækningen en afgørende rolle. Tv-mediet er fortsat de forskellige befolkningers primære kilde til viden om og fornemmelse for den fjerne verden, det viser en række danske og udenlandske undersøgelser, fx Viewing the World (2000), Verden langt herfra (2004) og Reflecting the Real World (2006).

Men, hvordan udvikler mediernes dækning af verden sig? Og 
hvilke konsekvenser har det? Hvor ligger der nye journalistiske udviklingspotentialer?

\section{En undersøgelse af faglitteratur}

Denne artikel er en videreudvikling af teserne og tankerne i et forskningspapir Global journalistik (Kabel, 2002). Videreudviklingen hviler på en systematisk kortlægning af den senest offentliggjorte danske og engelsksprogede faglitteratur om det medieskabte billede af ikke-vestlige lande og kulturer.

I en længere årrække har der blandt udenlandske og danske forskere og en del mediefolk været bred enighed om, at nyhedsmediernes billede af verden er ufuldstændigt. At medierne får fat i for få af virkelighedens mange virkeligheder. Der er også enighed om, at denne problematik er blevet forstærket af den intensivering af globaliseringsprocesserne, som har udspillet sig de seneste 10-15 år.

Sagen om Muhammed-tegningerne viste med klokkeklar tydelighed, at de nationale grænser omkring offentligheden er ved at smuldre - også omkring lille Danmark. Nok har vi ifølge medieforskere endnu ikke fået en fælles europæisk eller global offentlighed, men en integrationsproces med "increased connectedness across distance ... through which the national public sphere gradually becomes deterritorialized" (Hjarvard, 2001: 24) er under udvikling. Globale dagsordener kan pludseligt opstå og hurtigt bygges op.

Kulturelle manifestationer, hændelser og politiske begivenheder dækkes og modtages ikke længere alene i en national kontekst. Via især Internettet og 'media on demand' er den geografiske definition på en målgruppe og et publikum under nedbrydning. Som en engelsk tv-producent, Dorothy Byrne, fra Channel 4 udtrykker det: "The fact is, in ten years' time, if we make programmes about the developing world, they will be able to see them as they go out, simultaniously. People will just sit in Zimbabwe and watch it, and they'll be able to say to themselves, "well, thats really patronising", so they'll immediately send me their visual email comdemming me, which will be broadcast round the world", (Edge, Morris, Smith, 2006: 22). 
Denne artikel vil via litteraturstudier søge nogle svar på, hvordan mediebilledet af den globaliserede verden opfattes af læsere og tv-seere i tiden? Hvilke begreber og termer gør faglitteraturen brug af i dens kortlægning af den globaliserede mediedækning? Kan de bruges til en begrebsafklaring? Hvor er der nye arbejdsmetoder og ny inspiration at hente for journalister, redaktører og producenter i deres arbejde med journalistik om flere af verdens mange virkeligheder?

\section{Objekt for debat og kritik}

I lande som USA, Storbritannien, Holland og Danmark har der i årtier og i betydeligt omfang været sat kritisk fokus på, hvilke billeder af verden mediedækningen skabte og skaber. Problemstillingen har været analyseret og diskuteret helt tilbage til de første medie-publicerede fortællinger i anden halvdel af 180o-tallet, hvor fx journalisten Henry Stanley på en reportagerejse ind i det mørke Afrika i 1871 fandt Doktor Livingstone og senere rapporterede fra en opdagelsesrejse tværs gennem Afrika via Congo-floden.

De seneste 50-6o år i tilknytning til eksempelvis opbygningen af FN, det globale nødhjælpsarbejde, ulandsbistanden og Danida har problemstillingen været debatteret i Danmark gang på gang. Det viser blandt andet mediekritiske artikler fra det nu lukkede MS-blad, Kontakt.

I slutningen af 1980'erne og begyndelsen af 1990'erne blev den hjemlige debat om avisers og tv's stereotype dækning af især Afrika intensiveret via offentliggørelsen af forskningsrapporter som Images of Africa.

Denne artikel vil indledningsvist og kort gengive de væsentligste konklusioner fra de britiske og danske analyser, der er publiceret siden år 2000. Konklusionerne er tidligere offentliggjort $\mathrm{i}$ Danmark, men tåler en gentagelse. Det drejer sig om Verden på tilbud (2000), Viewing the World (2000), Making Sense of The World (2002), Meget større end du tror (2003), The World on the Box (2004) og Verden langt herfra (2005).

I 2006 sprang så det seneste skud på stammen ud. Det er et analysearbejde af en britisk forskergruppe offentliggjort i rappor- 
ten: Reflecting the Real World? How British TV Portrayed Developing Countries in 2005. Denne helt aktuelle kortlægning prioriteres højest i den kommende gennemgang.

\section{Det 'skæve' mediebillede}

På baggrund af BBC's og især BBC World's enorme betydning for radio- og tv-dækningen af verden har der i årtier været et højt niveau af kritisk opmærksomhed rettet imod BBC's stof om ulande og udviklingsprocesser.

I år 2000 blev en undersøgelse af BBC’s og andre britiske jordbaserede tv-kanalers dækning af udviklingslandene offentliggjort. Viewing the World vakte betydelig opmærksomhed i inderkredse. De britiske forskere bag rapporten sammenfattede:

- Der var en markant ubalance i den måde udviklingslandene blev portrætteret på, specielt i nyhederne, hvor dækningen var fokuseret på katastrofer, bizarre begivenheder eller besøg af prominente mennesker fra Vesten.

- Der var ubalance mellem dækningen, der fokuserede på en begrænset mængde af lande og emner og en udbredt interesse blandt seerne for en bred dækning af mennesker og samfund i den tredje verden. Seerne udtrykte ønsker om mere stof om almindeligt hverdagsliv, mindre om det usædvanlige og eksotiske.

- Nyhedsdækningen gav seerne et billede af den tredje verden i bestandig konflikt. I almindelighed havde folk et negativt billede af udviklingslandene, og de anklagede tv-nyhederne for at stå bag.

- Folk havde svært ved at forstå udviklingsprocesserne. Baggrunden for krig, katastrofer og terror blev for dårligt beskrevet.

- Seerne ønskede bedre mulighed for identifikation med de samfund og mennesker, der blev dækket. (Kabel, 2005: 15)

Analysen bag The World in the Box (2004) lagde i modsætning til de andre undersøgelser vægt på seertal og havde en mere kvantitativ tilgang. I denne konkluderede forskerne, at der frem til 2004 var sket en markant faldende prioritering af stoffet i Storbritannien: 
- Antallet af fakta-programmer er blevet halveret siden undersøgelsen begyndte i 1989/9o til det laveste antal nogensinde.

- Den samlede mængde af internationale faktaprogrammer var på de fire største landbaserede tv-kanaler 40\% lavere i 2003 end i 1989/90.

- På BBC 1 var der i 2003 kun et internationalt faktaprogram, der handlede om udvikling, miljø og menneskerettigheder. På ITV 1 var der ingen. (Kabel, 2005: 17)

\section{Mindre stat, mere samfund}

Undersøgelsen Meget større end du tror (2003) kortlagde danske avislæseres interesser inden for det internationale stof. Udgangspunktet var Jyllands-Postens udlandsdækning, og forskerne bag undersøgelserne kunne konkludere, at de følgende emner i prioriteret rækkefølge var dem, som avislæserne prioriterede højest:

- Naturkatastrofer

- Hverdagslivet i andre lande

- Miljøet i andre lande

- Menneskelige katastrofer

- Politik i andre lande

Analyserne i Meget større end du tror ledte til flere interessante konklusioner. Den vigtigste i denne sammenhæng er, at læserne ikke længere prioriterede den klassiske udenrigspolitiske beskrivelse af staterne og det internationale politiske system særligt højt. Læsernes præferencer for katastrofer, hverdagsliv og miljø relaterede sig ikke til stat, magt og politik. Læserne interesserede sig tilsyneladende ikke meget for politik og stater som fænomener, men mere for samfundet og individerne. De ønskede at få et dybere „indblik i det, der rører sig i det civile samfund“. (Haahr, Holm, 2003: 192) 


\section{Mindre dramatisering}

Analyserne bag Verden langt herfra (2005) bekræftede på mange måder pointerne fra de britiske undersøgelser med DR's og TV2's nyhedsudsendelser og faktaprogrammer som udgangspunkt.

De danske undersøgelser gik dog videre end de britiske. Især hvad angår analyser af brugen af nyhedskriterierne bag nyhedsprioriteringen. Verden langt herfra påviste et 'skævt' nyhedsbillede med op til 75 procents fokus på opgøret mellem Vesten og de muslimske lande og kulturer. TV2 og DR offentliggjorde i analyseåret 2003 en traditionel brændpunktsdækning, hvor „mellem 76 og 86 procent at tv-nyhederne handlede om nationale og isor internationale begivenheder hovedsageligt baseret på nyhedskriteriet konflikt“ (Kabel, 2005: 92).

Rapporten satte kritisk fokus på de journalistiske rutiner og tankegange under nyhedsproduktionen. Særligt blev det påpeget, at der kan identificeres en tendens i udlandsdækningen til rutinemæssigt at skabe effekt ved konsekvent at opprioritere konflikt og dramatiske hændelser. Og tv-seerne reagerede ifølge fokusgruppeundersøgelser negativt på dramatiseringen: „Kritikernes centrale pointe var, at dramatiseringen slører for indholdet. Sarligt var det dramatisering skabt via billedvalget, der vakte modvilje. De blodige, konfliktfyldte og ind imellem opstillede fotosituationer blev ofte til klichéer, der tilsyneladende ikke havde reel informationsvoerdi for seerne“.

„Det paradoksale er, at de tv-billeder, som nyhedsredaktionerne vaelger at bringe, netop fordi de vurderes at appellere til seernes følelser, efterhånden opleves som en udflydende masse af tomme klichéer og ulykkelige og negative indtryk".

„Denne overdramatisering er årsag til megen kritik og modvilje blandt seere“. (Kabel, 2005: 93)

\section{Et opbrud undervejs?}

På opdrag fra Commenwealth Broadcast Association har en forskergruppe undersøgt britisk tv's dækning af udviklingslande i 2005 med særligt fokus på mediebilledet af Afrika. Objektet for undersøgelsen var udenrigsstoffet i dokumentarer og magasin- 
programmer samt den del af de underholdende faktaprogrammer og film, der udspillede sig i 3. verdenslande. Nyhedsdækningen var også inddraget, men var ikke i fokus.

Undersøgelsen blev offentliggjort i rapporten Reflecting the Real World? How British TV portrayed developing countries in 2005, og den omfattede de landsdækkende britiske tv-kanaler, især BBC og Channel 4.

Seks fokusgruppeundersøgelser og kvalitative interview med 23 nøglepersoner havde til formål at fremkalde forskellige former for input om det tv-skabte billede af udviklingslandene, og det gjorde de da også. Billedet, som tv-seerne i Storbritannien dannede sig af den fjerne verden, var fortsat: "static, a one-dimensional images of desperation. Both positive and negative respondents associates the developing world with famine, poverty and disease. Peoples initial images was very often of starving babies with flies around their eyes" (Edge, Morris, Smith, 2006: 6).

Både 'indfødte' britiske seere fra fokusgrupperne og interviewede 2. og 3. generations indvandrere gav udtryk for, at mediedækningen i et betydeligt omfang er ansvarlig for befolkningens fortsat meget negative billede af udviklingslandene.

På baggrund af de samlede undersøgelser karakteriserede forskerne de britiske tv-seere som et "domestically oriented mainstream audience", og de påpegede med et citat af den tidligere Head of Current Affairs i BBC, Peter Horrocks, at "It is a paradox that people are better travelled and better educated than they have ever been and they're subject to more international influence, but in their media consumption they're probably more parochial (provinsiel)" (Edge, Morris, Smith, 2006: 16).

Seerundersøgelserne i Storbritannien i 2005 og 2006 blev på mange måder en gentagelse og en bekræftelse på de forestillinger om tv-billedet og tv-dækningens betydning for befolkningens opfattelse af den 3. verden, som de britiske og danske undersøgelser tidligere var nået frem til. Ikke meget nyt under solen på dette område, men alligevel beskriver Reflecting the Real World år 2005 som et epokegørende tv-år i Storbritannien. Denne konklusion bygger på en kortlægning af tv-stationernes programmer i 
2005 og fremstår som en konklusion på de kvalitative interview.

På flere centrale områder blev de klassiske redaktionelle opfattelser og prioriteringer fornyet:

For det første offentliggjorde $\mathrm{BBC}$ på hovedkanalen $\mathrm{BBC} 1$ gennem 2005 mange tematiserede faktaprogrammer, ren underholdning og en justeret nyhedsdækning under overskriften African Lives. Formålet var at få et mere positivt, afbalanceret og et mindre stereotypt tv-billede frem af Afrika i primetime på mainstream-kanalerne. Ambitionen lykkedes ifølge forskerne. Den kommercielle tv-kanal Channel 4 var med en tematiseret programserie under titlen Unreported World med på samme udvikling, og disse programmer fortsætter i 2006.

For det andet viste 2005 tegn på en større risikovillighed blandt redaktører, fladeplanlæggere og programproducenter end tidligere. Både de danske og de britiske undersøgelser har påvist, at programmer om den fjerne verden er blevet mere og mere marginaliseret på programfladen af frygt for lave seertal, hvad der i sig selv har ført til færre seere. Denne negative spiral blev blevet forsøgt brudt i 2005.

For det tredje var der tegn på, at "The sheer mass of programming about the developing world appears to have increased in 2005, reversing af consistent trend of decline". (Edge, Morris, Smith, 2006: 24).

For det fjerde byggede den kommercielle tv-station Channel 4's succesfulde redaktionelle satsnings på stoffet om udviklingslandene på seerundersøgelser af "what people would watch". Som de danske undersøgelser af avislæsere i 2003 også viste, så er der i befolkningen en udbredt interesse for udlandsstof.

Sidst, men ikke mindst var de britiske tv-programmer under African Lives og Unreported World ambitiøse i den forstand at: "2005 was a year that questioned some asumptions about media performance in representing the developing world: news producers returned to disaster stories to track progress, and some very complex issues - including poverty and debt, and climate changes - were tackled in popular news bulletins. Major primetime slots were given cover to diverse, more rounded and often celebratory coverage of the developing world contexts." (Edge, Morris, Smith, 2006: 24). 
Konklusionerne på undersøgelserne bag Reflecting the Real World er tosidede, de befinder sig i et spændingsfelt mellem, at britiske seere fortsat konkluderer, at udlandsstoffet efterlader dem med et traditionelt negativt og perspektivfattigt tv-billede af den fjerne verden, men på samme tid kan der på tv-stationernes programflader, i primetime og blandt redaktionelle ledere og producenter påvises opbrud og nye redaktionelle ambitioner.

\section{Et mønster og et opbrud}

De forskningsbaserede modtagerundersøgelser fra perioden 2000 til 2006 afdækkede til sammen et relativt ens mønster. Ifølge danske og britiske læsere og seere er det fortsat et billede af en konfliktfyldt og brændpunktfokuseret verden præget af sult, korruption og mangel på vestlig rationalisme, der tilbydes dem. Og de finder beskrivelsen utilstrækkelig.

Vores forståelse af 'de fremmede' og deres forståelse af os er et stykke hen ad vejen en konsekvens af den måde, hvorpå nyhedsmedierne dækker verden. Der er rigtigt mange ting, som er „ude af regeringers kontrol“, og kunne man tilføje: også uden for rækkevidde af regeringsapparaternes forståelse. Det 'fremmede' kan meget vel være lokaliseret i det nære nabolag. Den klassiske magtlogik er ikke længere givet som det vigtigste journalistiske væsentlighedskriterium bag nyhedsprioriteringerne.

Nyhedsmediernes utilstrækkelige dækning af de ikke-vestlige lande og kulturer bliver af mange betragtet som en del af forklaringen på det høje niveau af overraskelse, der lå bag de vestlige reaktioner på fx 11. september 2001 i USA og bombesprængningerne 7. juli 2005 i undergrundsbanen i London. Terrorhandlingerne kom uvarslede, blandt andet fordi medierne ikke havde identificeret og belyst de religiøse og kulturelle strømninger i fx Saudi Arabien og Nordengland, der lå til grund for handlingerne.

Mange af tidens mest virkelighedsforandrende processer er ikke et direkte resultat af politiske beslutninger og gennemført ved magt eller regeringsudøvelse. De foregår i subkulturer og sociale sammenhænge, ofte i nogle lag af virkeligheden, som den klassiske og ritualiserede udenrigspolitiske mediedækning ikke opfanger. 
Avislæsere og tv-seere i såvel Storbritannien som Danmark efterspørger mere mediedækning af de civile samfund, mere stof, der er forankret i 'almindelige' mennesker og deres hverdagsliv. Bedre muligheder for reel identifikation og forståelse.

Men problematikken er kompleks for samtidigt med, at de kritiske læser- og seeropfattelser hersker, så viser undersøgelserne af mediedækningen og interviewene med nøglepersonerne, at der er opbrud undervejs.

I Storbritannien bringer BBC og Channel 4 nu mere stof i primetime om Afrika og andre dele af den underrapporterede verden end tidligere. I Danmark har dagblade som Politiken rapporteret fra eksempelvis FN-konferencen i 2002 via slumkvarterer i Johannesburg, og Jyllands-Posten dækker på ottende år folkeliv jorden rundt via Explorer-holdenes reportager. De danske tvnyheder fra både DR og TV2 bruger jævnligt almindelige mennesker og deres livssituation som metaforer for nogle af tidens store globale problemstillinger. Der er på tv-stationerne en øget opmærksomhed på det redaktionelle potentiale i en fornyet journalistik og nyhedsdækning fra de civile samfund og om globaliseringsprocesserne.

I dette spændingsfelt mellem de veldokumenterede dækningsmønstre og det journalistiske opbrud vil den resterende del af denne artikel afsøge begreber og tankegange til brug i en udlandsjournalistik, der kommer tættere på.

\section{Om 'Global Journalism'}

'Global journalism' har været et 'buzz word' i udlandsdækningen det seneste tiår. Termens popularitet er forståelig i en tid, hvor mange typer af grænser bryder sammen, for hvad er mere nærliggende end så at udvikle et begreb for en grænseoverskridende journalistik? Også selv om der endnu ikke eksisterer en fælles global offentlighed.

Men hvad står 'global journalism' egentlig for? Hvordan defineres den? Er global journalistik navnet på den form for journalistik, der skal til for at opfange flere facetter af virkeligheden?

Disse spørgsmål er det ikke muligt i faglitteraturen at finde enslydende svar på, dog gives der flere typer af bud. Den amerikan- 
ske journalistikforsker Elfriede Fürsich definerer 'global journalism' med udgangspunkt i andre forskeres definitioner: "I use the term 'global journalism' to highlight the professional situation in a globalizing media system. Global journalists are not in Weaver's (1998) sense 'news people around the world'. Nor are they international journalists who cover foreign news from the perspective of one nation. The term 'global' relates to an increasing number of media workers who supply content to transnational media corporations and produce their content for a global market." (Fürsich, 2002: 59).

En anden definition på 'global journalism' tilbydes af britiske John Herbert. Han beskriver 'global journalism' som en måde at rapportere på: "Practising journalism means being there, bearing independent witness, reporting what is happening and then communicating this to the outside world". (Herbert, 2001: 5).

Herbert kobler også 'global journalism' med international nyhedsformidling: "Global news flow is all about journalists and their ability to find out what is happening in countries that aren't their own". (Herbert, 2001: 31)

Også undertegnede forsøgte sig i 2002 med en definition på global journalistik: „En udenrigsdoekning med flere facetter og andre typer af emner. En form for verdensjournalistik, der bygger på, at alverdens samfund ikke hovedsageligt kan beskrives og forstås via staterne, de politiske kampe, institutionerne, magthaverne og elite-kilderne. "(Kabel, 2002: 2 og 3)

Som det fremgår af citaterne, er 'global journalism' ikke en veldefineret term. Faglitteraturen rejser flere spørgsmål, end den giver svar: Er global journalistik fx kosmopolitiske nyhedsjournalister rundt om på jorden, der praktiserer international journalistik i en global kontekst? Er det en grænseoverskridende udenrigsdækning med et nationalt udgangspunkt? Er det journalistik defineret af offentliggørelseskanalerne, rettet mod de transnationale medier som CNN, BBC, Newsweek og International Tribune og målrettet et globalt marked? Eller er 'global journalism' en form for observeret og oplevelsesbetonet verdensjournalistik, der får fat i andre dimensioner af tilværelsen end den klassiske udenrigsjournalistik? 
Hvad termen 'global journalism' præcist står for, har der hverken manifesteret sig en redaktionel praksis på eller en enighed blandt journalistikforskerne om. Som en følge af den herskende begrebsforvirringen er det ikke hensigtsmæssigt at bruge 'global journalism' som fagterm for den fornyede journalistik, der ligger bag opbruddet i udlandsdækningen.

\section{Trækker i samme retning}

Selv om det journalistiske udviklingsarbejde og faglitteraturen ikke tilbyder et entydigt begrebsapparat og en klarhed om mål og metoder, så er der talrige data og initiativer, der trækker i den samme retning: Det handler om at udvikle en mere kultursensitiv journalistik og en international nyhedsdækning, der kommer tættere på livet i de mange, mange civile samfund, der eksisterer side om side jorden rundt. Det handler om et stykke journalistisk udviklingsarbejde, der går ud på at give et mere troværdigt billede af verden under den intensiverede globalisering, og som blandt andet har til ambition at: "Create more open texts and encourage multiple representations" (Fürsich, 2002: 1). Det handler om et journalistisk projekt, der hviler på, at "Different approaches may indeed have equal value" (Herbert, 2001: 3).

Den 'nye' kultursensitive journalistik er ikke en praksis, der naivt overser krig og brutalitet, miljøødelæggelser, slumkvarterer, malaria og kulturel fattigdom. Journalistikken idylliserer heller ikke tilværelsen i de eksotiske 3. verdenslande ved hovedsageligt at opsøge dyrelivet i nationalparkerne eller ved at møde de indfødte omkring bålene i landsbyerne.

Den kultursensitive journalistik erstatter ikke den ofte helt nødvendig internationale konflikt- og brændpunktjournalistik, men den supplerer den begivenhedsorienterede udenrigsjournalistik med beskrivelser af flere facetter af den vide verden. Den 'nye' udlandsdækning belyser og beskriver med udgangspunkt i globaliseringen såvel det hektiske byliv i de enorme metropoler, livet i forstædernes slum og betonkareer som den stille udvikling på landet.

Til en fornyet journalistisk praksis er de veletablerede nyhedskriterier og det elitære kildevalg utilstrækkeligt. De hviler på tra- 
ditioner fra en udenrigspolitisk dækning, der bygger på en klassisk magtlogik og på staternes og de forskellige 'shareholders' opgør om position og rigdom. Hvilket leder nyhedsmedierne og især tv-nyhederne lige ud i en beskrivelse af verden som én stor krigs- og kampzone. Og sådan er den globale virkelighed heldigvis kun de færreste steder, for relativt få mennesker. Det helt store flertal af os lever et andet liv. Dette liv er et vigtigt emne for både reportage og nyhedsdækning.

Kortlægningen af den 'nye' journalistiske praksis er inde i en tidlig fase. De foreløbige studier af faglitteraturen samt tidligere gennemført journalistisk udviklingsarbejde i Mumbai i Indien (2001) og Ho Chi Minh City i Vietnam (2002) viser, at der i blandt andre de følgende områder inden for journalistikkens metodeapparat er værdifuld faglig inspiration at hente i en kritisk og tværfaglig tilgang:

- Konfliktkriteriet koblet med kildevalget

- Den narrative fortælleform

- Journalistrollen - refleksion og selvrefleksion

\section{Med levevilkårstilgange}

Den massive brug af konflikt som det dominerende nyhedskriterium har været kortlagt og diskuteret i dansk og udenlandsk journalistikforskning i en årrække (Kramhøft, 2000; Ginneken, 2003; Kabel, 2005).

Med konfliktkriteriet som afsæt vælger journalister og nyhedsredaktioner ofte en bestemt type af begivenheder og kilder ud til dækning, og det fører til den form for udlandsjournalistik, som danske og britiske tv-seere og avislæsere stadigvæk er så kritiske over for.

Et journalistisk udviklingsarbejde gennemført i 2002 om konfliktkriteriet koblet med kildevalget ledte til følgende konklusioner i relation til dækningen af det moderne Vietnam: "Den traditionelle måde at se Vietnam på er i lyset af Vietnam-krigen, den danske udviklingshjoelp, det diktatoriske kommunistparti og konflikterne med nabolandene. Det fører ofte til artikler og anden journalistik om amerikanske krigsveteraner, vietnamesiske ofre for agent orange, narkotikamisbrug, danske udviklingsprojekter 
med succes, minoriteternes vanskelige livssituation, korruption, demokratisk underskud og faengslede oppositionspolitikere.

Ved siden af disse lag af virkeligheden er der imidlertid flere andre, som vietnameserne mener er ligeså vigtige eller måske endda vigtigere. Det er fortcellingerne om et 3 . verdensland i eksplosiv økonomisk udvikling. Om globaliseringens pres på den traditionelle kultur, og befolkningens resistens imod at overtage alle dens symboler. Om en driftig ivorkscetterkultur og opblomstring af mindre privat virksomhed. Det er nogle banale drømme om rigdom og social opstigning, en udbredt moral- og regelløshed og nogle sydøstasiatiske kapitalkræfters horgen. Sådanne historier opfanger man aldrig, hvis man som reporter eller fotograf ankommer til Vietnam og alene gør brug af de klassiske konflikt-indgange. Det går meget bedre med levevilkårstilgangene, der fx vil føre en journalist ud i de dynamiske forstadskvarterer $i$ Ho Chi Minh City, hvor Sydvietnams udvikling og fremtid i dag skabes“. (Kabel, 2002: 5 og 6).

\section{Narrativ orden}

Etnografien og antropologien er fag, hvorfra journalistikken via en tværfaglig tilgang kan hente værdifuld inspiration til udviklingen af den kultursensitive dækning. Etnografer advarer imod at skabe narrativ orden i uorden: „Skriv deskriptivt, ikke narrativt ... Narrativ er en fortolkning, der kan føre til overdrivelse af sammenhoenge ... De fleste tildragelser og møder mellem mennesker foregår ikke efter en drejebog som dramatiske historier, hvor en handling leder til den noeste og har skarpskårne konsekvenser. Livet udfolder sig ret formålsløst. Det at beskrive det $i$ narrativ form er en stcerk fortolkning“ (Krause-Jensen, 2006: 56).

Med inspiration fra 'visual anthropology' kritiserer også Fürsich især tv-journalistikkens fortælleformer, hvormed der ofte skabes afrundede nyhedsindslag: "Journalism in modernity tender to favor the presentation of a narrative leading to a solution or closure".

Den amerikanske forsker opfordrer til "instead of packing cultures ... a more open 'unpacking of cultures' by displaying many different aspects of the country covered" (Fûrsich, 2002: 78). 


\section{Den selvreflekterende journalist}

I årtier har det været en udbredt opfattelse på redaktionerne, at arbejdet med at researche og producere artiklerne og indslagene ikke vedkommer læserne eller tv-seerne. Afsenderpositionen er uvedkommende.

Denne opfattelse står for fald.

I både de danske og de udenlandske artikler og fagbøger er det en fælles konklusion, at den refleksive journalistik og den selvreflekterende journalist i dag er et udgangspunkt for at kunne lave en udlandsdækning, der får de mange facetter med. Det handler om at give modtagerne billeder af autentiske miljøer og hele mennesker, der er subjekter i deres egne liv og historier.

Fürsich anbefaler en strategi med: "Showing the production conditions of the programme." (Fürsich, 2002: 73) som en integreret del af tv-indslag og programmer.

I 2002 formulerede etnografen Camilla Rosengaard det således: „Refleksivitet er et grundvilkår, hvis det skal lykkes at lave trovaerdig journalistik om det civile liv. Refleksivitet forudscetter en interesse for forholdet mellem den verden, som journalisten reprcesenterer, og den fremmede verden, som han/hun vil beskrive. Det krcever, at journalisten ikke kun iagttager de andre, men også iagttager egne forudscetninger for at iagttage".

I 2006 formulerer Krause-Jensen det således: „Objektiviteten afhoenger af subjektiviteten, at man er i stand til at reflektere over sin egen position".

Den 'nye' kultursensitive journalistik om og fra de civile samfund er ikke fremtiden, den er nutiden. Mange reportere er i dag både refleksive i forhold til samfundene og selvreflekterende i forhold til journalist-rollen. På én eller anden måde indleder de ofte deres nyhedsindslag eller reportager fra den fjerne verden med et ... herfra hvor jeg står ... 


\section{REFEREN CER}

Fürsich, Elfried (2002). "How can global journalists represent the 'Others'?”, Journalism, Vol. 3, pp. $57-84$.

Ginneken, Jaap Van (2003). Global News, London: Sage.

Haahr, Jens Henrik og Hans-Henrik Holm (2003). Meget større end du tror, Århus: Forlaget Ajour.

Herbert, John (2001). Practicing Global Journalism, London \& New York: Focal Press.

Hjarvard, Stig (red.) (2001). News in a Globalized Society, Göteborg: Nordicom.

Holm, Hans-Henrik, Lars Kabel m.fl. (2000). Verden langt herfra, Århus: CFJE/Forlaget Ajour.

Kabel, Lars (2002). Global journalistik, Århus: CFJE online.

Kabel, Lars (2005). Verden langt herfra, Århus: CFJE og Danida.

Kramhøft, Peter (2000). Journalistik med omtanke, Århus: Forlaget Ajour.

Krause-Jensen, Jakob (2006). „Journalistisk undren og kunsten at konkludere på observationer“, pp. 39-58 i Flemming Svith (red.), At opdage verden. Fra akademikere til journalister, Århus: Forlaget Ajour. Smith, Joe, Lucy Edge \& Vanessa Morris (2006). Reflecting the real World? How British TV portrayed developing countries in 2005, London: Commonwealth Broadcasting Association, Department for international Development, International Broadcasting Trust, The Open University \&VSO. 